\title{
Касимов P.P. \\ Конструирование квалифицирующих признаков состава контрабанды наличных денежных средств и (или) денежных инструментов (ст.200.1 УК РФ)
}

ФГБОУ ВО «Саратовская государственная юридическая академия» (Россия, Саратов)

doi: 10.18411/trnio-10-2021-118

\section{Аннотация}

В статье анализируются логические противоречия и пробелы, допущенные законодателем при конструировании квалифицирующих признаков состава контрабанды наличных денежных средств и (или) денежных инструментов. Были сформулированы авторские предложения по внесению изменений и дополнений в ст.200.1 УК РФ.

Ключевые слова: контрабанды наличных денежных средств и (или) денежных инструментов, таможенная граница Таможенного союза, организованная группа, должностное лицо, группа лиц по предварительному сговору.

\section{Abstract}

The article analyzes some logical contradictions and gaps made by the legislator when designing qualifying signs of the composition of smuggling of cash and (or) monetary instruments. The author's proposals for making amendments and additions to Article 200.1 of the Criminal Code of the Russian Federation were formulated.

Keywords: smuggling of cash and (or) monetary instruments, customs border of the Customs Union, organized group, official, group of persons by prior agreement.

Федеральным законом от 28 июня 2013г. №134-Ф3 «О внесении изменений в отдельные законодательные акты Российской Федерации в части противодействия незаконным финансовым операциям» глава 22 УК РФ «Преступления в сфере экономической деятельности» была дополнена ст.200.1, предусматривающая ответственность за контрабанду наличных денежных средств и (или) денежных инструментов. Статья 200.1 УК РФ состоит из двух частей, в части первой содержаться признаки основного состава преступления, а во второй части закреплены квалифицирующие признаки.

Необходимо отметить, что в УК РФ помимо статьи 200.1, имеется еще три состава преступления, предусматривающие ответственность за контрабанду (статьи 200.2, 226.1, 229.1 УК РФ), но во всех этих деяниях содержится разный «набор» квалифицирующих признаков. Объяснить данный факт, наверное, можно тем, что законодатель при конструировании этих норм учитывал, в первую очередь, общественную опасность самого предмета преступления, перемещаемого через государственную границу Таможенного союза. Но, мы считаем, так как суть контрабанды во всех этих статьях одна и та же, то и количество и качество квалифицирующих признаков должно быть одним и тем же.

Часть 2 ст.200.1 УК РФ предусматривает повышенную уголовную ответственность за контрабанду наличных денежных средств и (или) денежных инструментов, совершенную в особо крупном размере или группой лиц. Именно размер перемещаемых через государственную границу Таможенного союза денежных средств и (или) денежных инструментов позволяет отграничить данный состав преступления от административного правонарушения (ст.16.4 КоАП РФ).

Согласно примечанию 1 к данной статье, особо крупным размером признается сумма незаконно перемещенных наличных денежных средств и (или) стоимость незаконно перемещенных денежных инструментов превышающая пятикратный размер суммы наличных денежных средств и (или) стоимости дорожных чеков, разрешенных таможенным законодательством Таможенного союза в рамках ЕврАзЭС к перемещению без письменного декларирования. То есть, в случае единовременного провоза через государственную границу 
наличных денежных средств и (или) денежных инструментов на общую сумму эквивалентную 10000 долл. США, она не подлежит декларированию в письменном виде [1, c. 124-128.]. Соответственно, если такая сумма будет превышать 10000 долл. США, то она требует таможенного декларирования. Для квалификации деяния по п. «а» ч.2 ст.200.1 УК РФ необходимо чтобы лицо незаконно перемещало через таможенную границу наличные денежные средства и (или) денежные инструменты в размере свыше 50 тыс. долларов США.

Понятие группы лиц закреплено в ч.1 ст.35 УК РФ. Согласно данной статье, преступление признается совершенное группой лиц, если в нем участвовало два или более лица без предварительного сговора. Как правило, это такие случаи, когда одно лицо уже начало выполнять объективную сторону какого-либо преступления, а другое лицо с этой же целью к нему присоединилось, или же спонтанное совершение преступления. Но, на практике подобные случаи встречаются редко. Чаще всего контрабанда наличных денежных средств, денежных инструментов совершается группой лиц по предварительному сговору или организованной группой, но эти формы соучастия не закреплены в ч.2 ст.200.1 УК РФ.

Преступление признается совершенной группой лиц по предварительному сговору, если в нем участвовали лица, заранее договорившееся о совместном совершении преступления. Совершить контрабанду в составе группы лиц по предварительному сговору намного проще, как правило, такие преступления тщательно готовятся, лица распределяют между собой все роли. Совместное усилие нескольких лиц существенно облегчает совершение преступления. У группы лиц по предварительному сговору имеется возможность для перемещения большего количества предметов, ограниченных или запрещенных к провозу через государственную границу Таможенного союза [2, с. 87.]. Представляется, что для статьи 200.1 УК РФ этот квалифицирующий признак является актуальным, и соответственно его необходимо закрепить также в ч.2 ст.200.1 УК РФ.

Организованная группа - это устойчивая группа лиц, заранее объединившихся для совершения одного или нескольких преступлений. Об устойчивости данной группы свидетельствуют такие признаки, как стабильность состава участников и длительность существования [3]. Согласно сложившейся судебной практике, все лица, независимо от той роли, которую они выполняли в организованной группе, признаются исполнителями преступления. Данная форма соучастия закреплена в качестве квалифицирующего признака в статьях 200.2 и 226.1 УК РФ. В связи с чем, было бы логично дополнить статью 200.1 УК РФ подобным отягчающим обстоятельством.

Необходимо остановиться еще на одном возможном квалифицирующем признаке контрабанды, а именно «контрабанда, совершенная с применением насилия к лицу, осуществляющему таможенный или пограничный контроль». Данный признак отсутствует в рассматриваемом нами составе преступления, но он имеет место быть в таких деяниях, как контрабанда, предусмотренная статьями 226.1 и 229.1 УК РФ.

С учетом существующих мнений, в самом общем виде насилие можно определить, как воздействие одного человека на другого. Такому воздействию могут подвергаться организм (тело) человека, его сознание (психика), или воля (поведение). В этом смысле насилие состоит в физическом и (или) психическом воздействии, которое может лишать или ограничивать волеизъявление потерпевшего.

В уголовном праве насилие традиционно разделяют на физическое и психическое насилие. Рассматривая физическое насилие в самом общем виде, его можно представить, как причинение соматического, телесного вреда человеку, вплоть до лишения его жизни.

Рассматривая «психическое насилие», стоит обратить внимание на нерешенность вопроса относительно его содержания. Так, часть авторов под психическим насилием подразумевает причинение душевной травмы, при этом, уточняя, что оно не обязательно сопровождается причинением реального или же потенциального физического вреда. В своих работах Л.А. Прохоров писал, что психическое насилие есть ни что иное как непосредственное воздействие на организм человека, оказывающее влияние на его психику [4. c. 58]. 
Осуществить воздействие подобного рода можно при помощи психических факторов внешней среды, что и формирует содержание психического насилия.

Также упоминается, что под психическим насилием понимается любое воздействие на психику для преодоления воли потерпевшего и достижения требуемого преступного результата [4. с. 58].

В своем видении Ю.М. Антонян производит разделение психического насилия на две группы. Первая группа включает угрозы применения насилия, причинения вреда здоровью или жизни, а также неконкретизированные угрозы с аналогичным содержанием. Во вторую группу он включает угрозы с меньшей степенью опасности, такие как шантаж и вымогательство, не направленные на причинение вреда жизни и здоровья [5. с. 54-55].

Представляется более правильным под психическим насилием понимать умышленное и целенаправленное, противоправное и общественно опасное воздействие на психику человека, совершаемое помимо или против его воли, которое может повлечь негативные последствия для жизни или здоровья человека или же создать угрозу возникновения таких последствий. Как правило, большинство статей УК РФ точно определяет вид и степень опасности насилия. Выделяют в связи с этим насилие не опасное для жизни или здоровья потерпевшего лица, либо угрозу применения такого насилия, и соответственно, насилие опасное для жизни или здоровья потерпевшего лица, либо угрозу применения такого насилия. В рамках п. «б» ч.2 ст.226.1 УК РФ законодатель не указывает вид насилия, соответственно, можно придти к выводу, что здесь имеется в виду любой вид насилия. В уголовном законе, как правило, законодатель угрозу применения насилия приравнивает по степени общественной опасности к самому насилию. Исходя из изложенного, считаем необходимым ч.2 ст.200.1 УК РФ дополнить таким квалифицирующим признаком, как «деяние, предусмотренное частью первой настоящей статьи, совершенное с применением насилия, не опасного для жизни или здоровья или с угрозой его применения к лицу, осуществляющему таможенный или пограничный контроль», насилие, опасное для жизни или здоровья или с угрозой его применения к таким лицам, закрепить уже в части третьей рассматриваемой статьи.

Предложенные нами нововведения позволят на практике более эффективно противодействовать контрабанде наличных денежных средств и (или) денежных инструментов.

$$
* * *
$$

1. Марковский М.С. К вопросу об объекте контрабанды наличных денежных средств и (или) денежных инструментов // Вестник Московского университета МВД России. 2015. № 8. С. 124-128.

2. Пащенко Н.Н. Квалифицированные виды контрабанды наличных денежных средств и (или) денежных инструментов //Общество: политика, экономика, право. 2018. №10 (63). С.87-90.

3. Судебная практика также делает акцент на данные признаки. См., например: Дело № 1-14/09 // Архив Нижегородского районного суда г. Нижнего Новгорода. 2009.

4. Прохоров Л.А., Прохорова М.Л. Уголовное право. М, 2005. 480с.

5. Антонян Ю. М. Преступная жестокость. М., 1994. $216 \mathrm{c}$.

\section{Краснов А.А., Васильев А.М. \\ Преступления, совершенные несовершеннолетними: проблемы применения наказаний} ФГБОУ ВО «Кубанский государственный университет» (Россия, Краснодар)

doi: 10.18411/trnio-10-2021-119

\section{Аннотация}

В данной научной работе рассматриваются актуальные проблемы применения наказаний в виде мер уголовно-правового характера для несовершеннолетних. Нами приводится краткий, но на наш взгляд уместный для научного изыскания анализ статистических показателей по применению наказаний для несовершеннолетних, а также 